\title{
KETAHANAN PAPAN KOMPOSIT DARI LIMBAH KAYU SENGON DAN KARTON TERHADAP RAYAP KAYU KERING DAN RAYAP TANAH
}

\author{
The Resistance of Composite Boards Made from Sengon Wood Waste and Carton on Drywood Termite \\ and Subterranean Termite
}

Suhasman, Muh. Yusram Massijaya, Yusuf Sudo Hadi, dan Astuti Arif

\begin{abstract}
This study was aimed to analyze the resistance of composites board made from wafer and carton or paper overlaid on drywood termite and subterranean termite. Materials used in this study were wafer from sengon wood (Paraserianthes falcataria L. Nielsen), water based polymer isocyanate adhesive, veneer, and several kind of carton and paper such as duplex carton, recycle carton, corrugate board, and waste of cement sack. The target density was $0.65 \mathrm{~g} / \mathrm{cm}^{3}$, while the resin solid content was $6 \%$. The result of this study showed that no significantly different on infection rate of drywood termite among of composite board types and solid wood. The weight loose of composites board were 1.2-3.8\%, while solid wood was $2.7 \%$. Composites board more favorable to infection Macrotermes gilvus than solid wood. The weight loose of composites board were $19.3-28.8 \%$, while solid wood was $12.6 \%$.
\end{abstract}

Key words: Composites board, drywood termite, subterranean termite

\section{PENDAHULUAN}

Akibat semakin terbatasnya bahan baku kayu, inovasi untuk menghasilkan papan komposit berkualitas tinggi dengan memanfaatkan bahan baku berkualitas rendah perlu terus dilakukan. Comply adalah salah satu jenis papan komposit yang memiliki kekuatan cukup tinggi akibat adanya lapisan finir yang memiliki kekuatan tarik tinggi pada kedua permukaannya. Namun demikian, dikarenakan suplai bahan baku kayu berdiameter besar yang merupakan bahan baku pembuatan finir semakin menurun, maka perlu dicari bahan yang dapat mensubstitusi finir tersebut dan dapat dibuat dari bahan baku berkualitas rendah.

Penelitian terdahulu (Suhasman et al., 2005) menunjukkan bahwa penggunaan bahan pelapis dari berbagai jenis karton dan kertas dapat meningkatkan sifat fisik dan mekanis papan. Karton dan kertas dapat dibuat dari bahan baku berkualitas rendah seperti log diameter kecil, limbah, produk daur ulang, dan bahan lignosellulosa non kayu. Dengan demikian penggunaan lapisan karton atau kertas sebagai bahan subtitusi finir potensial untuk dikembangkan.

Penelitian lebih lanjut perlu dilakukan untuk mengetahui ketahanan papan komposit terhadap agen biodeteriorasi, khususnya rayap. Sebagai negara kepulauan dengan iklim tropis, Indonesia adalah daerah yang sangat sesuai bagi perkembangan kehidupan rayap. Rayap diketahui sebagai agen biodeteriorasi terpenting di Indonesia. Kerugian yang ditimbulkannya ditaksir mencapai Rp. 2,80 trilyun pada tahun 2000 (Nandika et al., 2003). Mengingat besarnya ancaman kerugian tersebut, maka informasi ketahanan sebuah produk terhadap serangan rayap sangat penting diketahui.

Papan komposit berlapis karton dan kertas yang memiliki kandungan sellulosa yang tinggi diduga rentan mengalami serangan rayap, tetapi di sisi lain, penggunaan waterbased polymer isocyanate sebagai perekat dalam pembuatan papan komposit diharapkan dapat menurunkan resiko serangan. Sebagaimana dikemukakan oleh Weaver dan Owen (1992), penggunaan isosianat dapat meningkatkan ketahanan kayu terhadap biodeteriorasi, sifat hydrophobic, dan kekuatan mekanis.

Penelitian ini dilaksanakan dengan tujuan untuk mengetahui ketahanan papan komposit terhadap rayap tanah dan rayap kayu kering. Papan komposit yang diteliti adalah papan komposit yang dibuat dari wafer dengan berbagai jenis bahan pelapis yaitu finir, karton dupleks, karton daur ulang, karton gelombang, dan limbah kantong semen. 


\section{BAHAN DAN METODE}

\section{Bahan}

Bahan yang digunakan berupa wafer dari jenis kayu sengon (Paraserianthes falcataria $L$ Nielsen), pelapis dari karton, kertas, dan finir dari kayu waru (Hibiscus teleaceus), perekat water based polymer isocyanate yang terdiri atas dua komponen yaitu resin tipe PI 3200 dan hardener tipe H3M produksi PT Polychemie Asia Pacific Permai Jakarta, rayap kayu kering dan rayap tanah. Karton dan kertas yang digunakan terdiri atas 4 jenis yaitu : karton daur ulang, karton dupleks, limbah karton gelombang, dan limbah kantong semen dari jenis kertas kraft. Spesifikasi bahan finir dan karton atau kertas yang digunakan disajikan pada Tabel 1.

\section{Metode}

\section{Konstruksi Papan}

Untuk mengetahui ketahanan papan komposit dengan berbagai jenis bahan pelapis terhadap rayap, maka papan komposit dibuat dalam 7 jenis yaitu : papan berlapis finir (VR), papan berlapis karton dupleks (DP), papan berlapis karton daur ulang tanpa perlakuan (DU), papan berlapis karton daur ulang yang telah dicelup resin (DU-cr), papan berlapis limbah kantong semen (KS), papan berlapis karton gelombang (KG), serta papan tanpa lapisan ( $\mathrm{TL})$.

\section{Pembuatan Papan}

Kayu sengon dibuat menjadi partikel berbentuk wafer dengan dimensi rata-rata $2 \mathrm{~cm}, 2$ $\mathrm{cm}$, dan 2,25 mm untuk ukuran panjang, lebar, dan tebal. Wafer kemudian dikeringudarakan dan dilanjutkan dengan pengeringan dalam oven pada suhu $60^{\circ} \mathrm{C}$ untuk mencapai kadar air $2-4 \%$.
Lembaran karton dan kertas dipotong dengan ukuran $30 \mathrm{~cm}$ x $30 \mathrm{~cm}$. Sebelum digunakan, karton gelombang dicelup dalam resin isosianat dengan kadar padatan (solid content) 15\% selama 2 menit kemudian ditiriskan. Untuk menghilangkan gelombangnya, karton dikempa dingin selama 2 menit dengan tekanan $10 \mathrm{kgf} / \mathrm{cm}^{2}$ kemudian dikeringkan dalam oven pada suhu $60{ }^{\circ} \mathrm{C}$ selama 24 jam. Karton daur ulang digunakan dalam 2 jenis, yaitu digunakan langsung sebagai face/back dan yang lainnya diberi perlakuan pencelupan dalam resin. Karton daur ulang dicelup resin selama 2 menit kemudian ditiriskan lalu dioven bersama dengan karton gelombang. Karton dupleks dan limbah kantong semen digunakan langsung tanpa perlakuan.

Pembuatan papan dilakukan dengan terlebih dahulu menimbang bahan-bahan yang digunakan. Kadar perekat yang digunakan adalah $6 \%$ dari berat kering kayu dan bahan pelapis. Setelah ditimbang, wafer dimasukkan ke dalam blender lalu disemprot dengan perekat menggunakan spray gun. Pelaburan perekat pada lembaran facelback dilakukan dengan menyemprotkan perekat pada permukaannya dengan berat resin cair untuk setiap lembar facelback rata-rata $2 \mathrm{~g}$ atau setara dengan $0,4 \mathrm{~g}$ kadar padatan resin. Untuk jenis pelapis finir, karton gelombang, karton dupleks, dan karton daur ulang, jumlah pelapis masing-masing 1 lapis untuk face dan back sedangkan untuk limbah kantong semen digunakan masing-masing 4 lapis untuk face dan back. Wafer yang telah tercampur perekat beserta bahan pelapis kemudian dicetak menjadi lembaran papan pada mesin kempa panas dengan suhu $130^{\circ} \mathrm{C}$, tekanan $25 \mathrm{~kg} / \mathrm{cm}^{2}$ selama 15 menit. Papan kemudian dikondisikan selama 14 hari sebelum dipotong menjadi contoh uji. Papan yang dibuat berukuran $30 \times 30 \mathrm{~cm}$ dengan tebal $1 \mathrm{~cm}$ serta kerapatan sasaran $0,65 \mathrm{~g} / \mathrm{cm}^{3}$.

Table 1. Material specifications

\begin{tabular}{|c|c|c|c|c|}
\hline No. & Jenis Partikel dan pelapis & Tebal (mm) & $\begin{array}{c}\text { Gramatur } \\
\left(\mathrm{g} / \mathrm{m}^{2}\right)\end{array}$ & $\begin{array}{c}\text { Kerapatan } \\
\left(\mathrm{g} / \mathrm{cm}^{3}\right)\end{array}$ \\
\hline 1. & Kayu sengon & 2,25 & - & 0,36 \\
\hline 2. & Finir (VR) & 1,46 & - & 0.50 \\
\hline 3. & Karton dupleks (DP) & 0,60 & 471,48 & 0,79 \\
\hline 4. & Karton daur ulang (DU) & 0,85 & 506,80 & 0,60 \\
\hline 5. & Karton daur ulang dicelup resin (DU-cr) & 0,85 & 543,15 & 0,64 \\
\hline 6. & Limbah kantong semen (KS) & 0,10 & 82,89 & 0,83 \\
\hline 7. & Karton gelombang dinding tunggal (KG) & $2,85 / 0,9^{*}$ & 435,36 & $0,15 / 0,48^{* *}$ \\
\hline
\end{tabular}




\section{Pengujian Ketahanan Papan Komposit Terhadap Serangan Rayap}

Pengujian ketahanan papan terhadap serangan rayap dilakukan pada rayap kayu kering dan rayap tanah. Pengujian terhadap rayap kayu kering dilakukan secara laboratoris sedangkan pengujian terhadap rayap tanah dilakukan dengan uji lapangan (uji kubur).

Pengujian terhadap rayap kayu kering dilakukan dengan terlebih dahulu mengukur berat awal contoh uji. Contoh uji kemudian dimasukkan ke dalam kotak kaca berukuran $5 \mathrm{~cm} \times 4,5 \mathrm{~cm}$ x $3,5 \mathrm{~cm}$. Ke dalam kotak kaca tersebut dimasukkan rayap kayu kering yang aktif dan sehat sebanyak 50 ekor. Kotak kaca kemudian ditutup dengan kain kasa lalu ditempatkan di ruang gelap. Contoh uji disimpan selama 28 hari dan setiap selang 7 hari dilakukan pengamatan terhadap jumlah individu rayap yang mati. Pada akhir pengamatan, contoh uji ditimbang untuk mengetahui kehilangan berat akibat serangan rayap.

Persentase jumlah individu rayap yang mati (mortalitas) dihitung dengan rumus sebagai berikut:

$$
\text { Mortalitas (\%) }=\mathrm{A} / \mathrm{B} \times 100 \%
$$

Keterangan:

$A=$ Jumlah individu rayap yang mati

$\mathrm{B}=$ Jumlah individu rayap yang diumpankan per contoh uji

Persentase pengurangan bobot akibat serangan rayap dihitung dengan rumus:

Pengurangan bobot $(\%)=(\mathrm{W} 0-\mathrm{W} 1) / \mathrm{W} 0 \times 100 \%$

Keterangan:

WO = Bobot contoh uji sebelum diumpankan ke rayap $(\mathrm{g})$

$\mathrm{W} 1$ = Bobot contoh uji setelah diumpankan ke rayap $(\mathrm{g})$

Pengujian terhadap rayap tanah dilakukan dengan metode uji kubur (grave yard test). Contoh uji yang telah ditimbang berat awalnya ditancapkan $1 / 2$ bagian $(10 \mathrm{~cm})$ ke dalam tanah. Pengumpanan dilakukan di Arboretum Fakultas Kehutanan IPB di mana terdapat koloni rayap tanah Macrotermes sp, Microtermes sp, dan Coptotermes sp. Pengamatan dilakukan setiap minggu untuk mengamati aktivitas rayap, sementara penghitungan kehilangan berat contoh uji dilakukan setelah 1 bulan pengumpanan.

\section{Analisis Data}

Penelitian ini dilakukan dengan menggunakan 5 ulangan untuk setiap jenis papan, sehingga jumlah keseluruhan papan sebanyak 35 lembar (7 jenis) serta sebagai kontrol digunakan kayu solid dari kayu sengon dengan ulangan yang sama. Dengan demikian dalam penelitian ini terdapat 40 satuan unit pengamatan. Nilai rata-rata untuk masing-masing parameter yang diamati dibandingkan satu sama lain untuk mengetahui ketahanan setiap jenis papan terhadap rayap kayu kering dan rayap tanah.

\section{HASIL DAN PEMBAHASAN}

\section{Kerapatan (Density)}

Kerapatan papan merupakan salah satu faktor yang dapat mempengaruhi aktifitas makan rayap. Papan dengan kerapatan yang tinggi cenderung lebih keras sehingga secara tidak langsung menjadi penghambat aktifitas makan rayap secara fisik. Perlakuan pengempaan pada suhu tinggi dalam pembuatan papan komposit akan meningkatkan kerapatan papan sehingga menjadi lebih keras dibandingkan dengan kayu solid dari jenis kayu yang sama. Nilai kerapatan masing-masing jenis papan serta kayu solid disajikan pada Gambar 1.

Berdasarkan hasil pengujian, nilai kerapatan papan berkisar antara 0,60 sampai $0,70 \mathrm{~g} / \mathrm{cm}^{3}$, sementara kayu solid sebesar $0,36 \mathrm{~g} / \mathrm{cm}^{3}$. Histogram pada gambar tersebut menunjukkan bahwa papan komposit tanpa lapisan memiliki kerapatan tertinggi, sedangkan kerapatan terendah diperoleh pada papan dengan face/back karton gelombang. Perbedaan kerapatan ini disebabkan variasi ketebalan akhir papan yang dicapai. Meskipun tebal sasaran telah ditetapkan sebesar 1 $\mathrm{cm}$ namun terdapat papan yang tebalnya kurang atau lebih dari tebal sasaran.

\section{Kadar Air (Moisture content)}

Hasil pengujian menunjukkan bahwa kadar air papan berkisar antara $8,4-10,8 \%$, sementara kadar air kayu solid sebesar $15,2 \%$. Data nilai kadar air untuk setiap jenis papan disajikan pada 


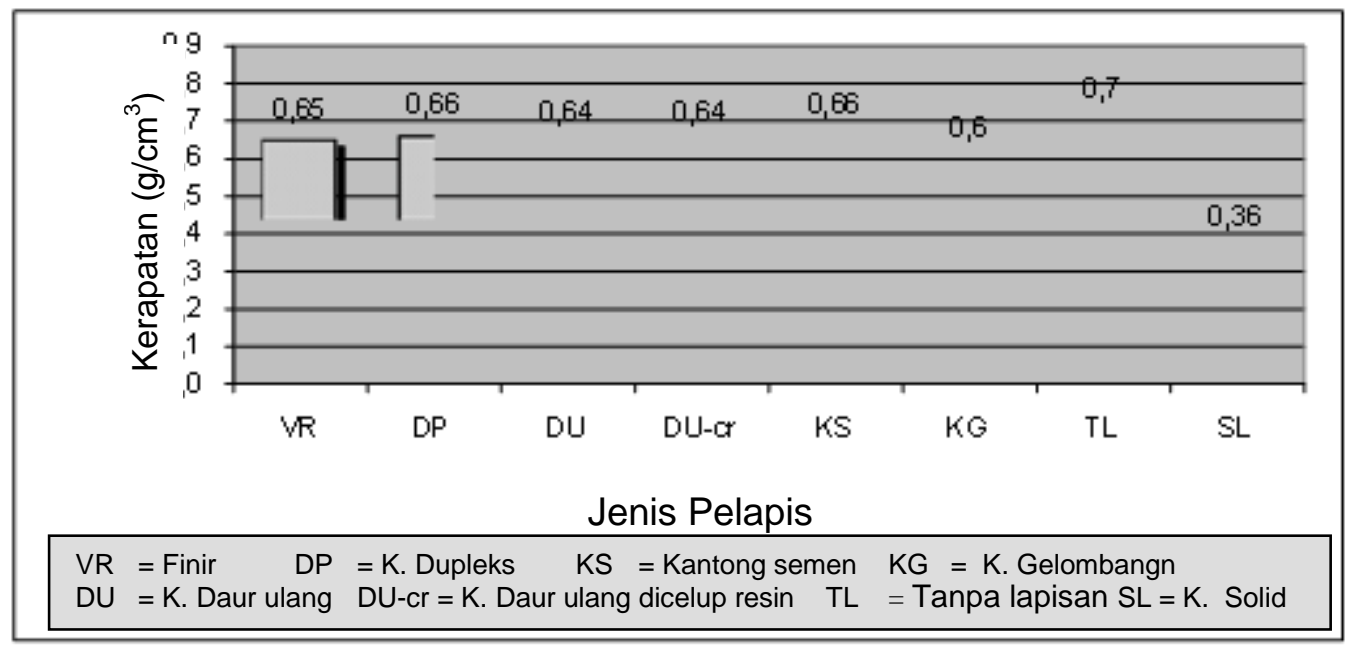

Figure 1. Histogram of composite boards and solid wood densities

Gambar 2. Dari histogram tersebut terlihat bahwa papan tanpa lapisan memiliki kadar air terendah $(8,4 \%)$, sementara papan komposit berlapis karton gelombang memiliki nilai kadar air paling tinggi $(10,8 \%)$. Dalam proses pembuatan papan komposit, kadar padatan resin yang digunakan untuk seluruh papan adalah sama. Dengan demikian variasi kadar air papan tidak dipengaruhi oleh kadar air perekat. Variasi tersebut disebabkan oleh kadar air wafer antara satu papan dengan papan lainnya. Selain itu, tingginya kadar air papan dengan pelapis karton gelombang juga disebabkan sifat karton gelombang yang relatif lebih mudah mengikat air dalam proses pengkondisian. Nilai kadar air keseluruhan papan lebih rendah dari kayu solid. Hal ini terjadi karena kayu solid hanya dikeringudarakan, sementara dalam proses pembuatan papan komposit, wafer terlebih dahulu dioven sampai kadar air $2-4 \%$ serta dalam proses pencetakan dilakukan kempa panas. Tampaknya, perlakuan kempa panas selama 15 menit pada suhu $130^{\circ} \mathrm{C}$ berperan dalam menurunkan sifat higroskopisitas kayu, sehingga meskipun telah dilakukan pengkondisian selama 14 hari, kadar air kesetimbangan yang dicapai tetap lebih rendah dari kadar air kesetimbangan kayu solid.

Kadar air papan dapat mempengaruhi aktivitas makan rayap, di mana rayap tanah cenderung menyukai kondisi dengan kelembaban tinggi sementara rayap kayu kering cenderung menyukai kondisi yang lebih kering. Namun demikian jika dilihat dari nilai kadar air masingmasing papan yang relatif sama, maka kondisi kadar air papan ini tidak akan memberikan pengaruh yang berbeda terhadap intensitas serangan rayap pada ketujuh jenis papan.

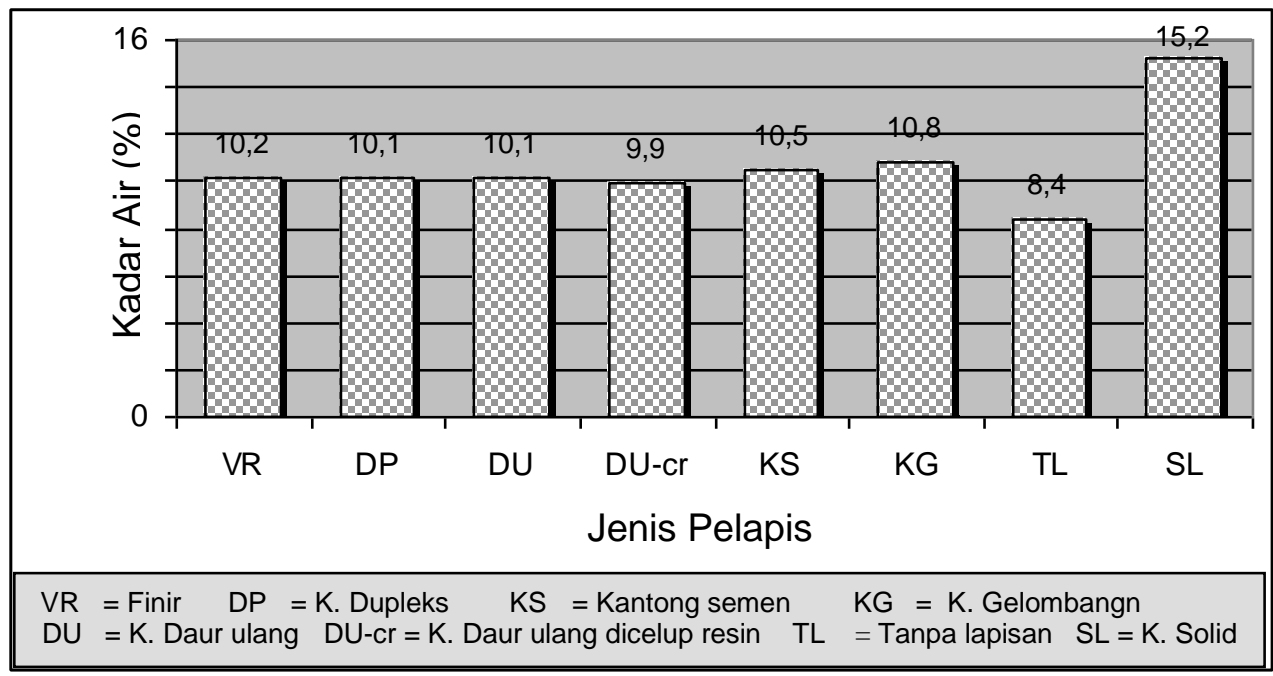

Figure 2. Histogram of moisture content of composite boards and solid wood 
Table 2. Termite mortalitas during 1 st -4 th weeks observation

\begin{tabular}{lcccc}
\hline \multirow{2}{*}{ Jenis Pelapis } & \multicolumn{4}{c}{ Mortalitas Rayap (\%) } \\
\cline { 2 - 5 } & 1 & 2 & 3 & 4 \\
\hline Finir (VR) & 29 & 36 & 44 & 50 \\
Karton dupleks (DP) & 32 & 42 & 50 & 56 \\
Karton daur ulang (DU) & 39 & 52 & 63 & 71 \\
Karton daur ulang dicelup resin (DU-cr) & 34 & 40 & 48 & 56 \\
Kantong semen (KS) & 18 & 25 & 29 & 35 \\
Karton gelombang (KG) & 42 & 52 & 60 & 66 \\
Papan tanpa lapisan (TL) & 38 & 44 & 51 & 56 \\
Kayu solid (SL) & 23 & 31 & 37 & 42 \\
\hline
\end{tabular}

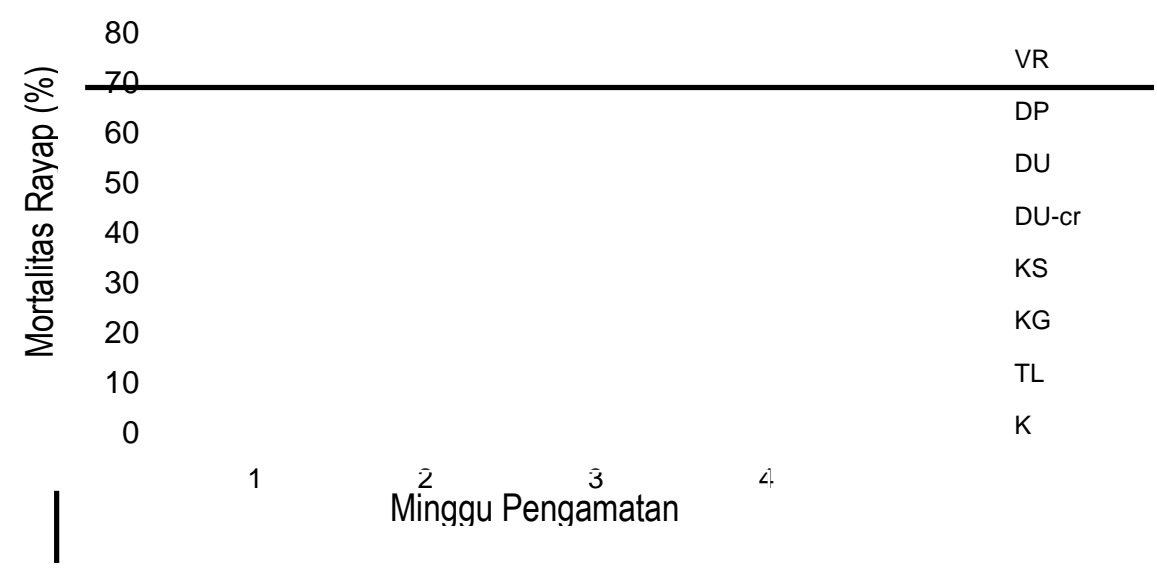

Figure 3. Graph of Termite mortality levels on each week observation

\section{Ketahanan Terhadap Rayap Kayu Kering (Cryptotermes cynocephalus Light)}

Hasil pengamatan terhadap tingkat mortalitas komulatif rayap pada setiap minggunya menunjukkan bahwa tingkat mortalitas rayap pada minggu I cenderung tinggi yaitu berkisar $23-42 \%$. Mortalitas yang tinggi ini disebabkan rayap mengalami stress selama pemindahan dari koloninya ke dalam kotak pengamatan contoh uji. Tingkat mortalitas rayap setiap periode pengamatan disajikan pada Tabel 2.

Data dan gambar di atas menunjukkan bahwa pada akhir pengamatan, sebagian besar tingkat mortalitas rayap sudah di atas $50 \%$ yang berarti lebih dari setengah jumlah individu rayap telah mati. Hanya papan komposit berlapis kantong semen dan kayu solid yang memiliki tingkat mortalitas di bawah $50 \%$.

Selanjutnya berdasarkan hasil perhitungan kehilangan berat papan, ternyata papan tanpa lapisan mengalami kehilangan berat tertinggi $(3,84 \%)$, sementara kehilangan berat terendah terjadi pada papan berlapis karton daur ulang $(1,21 \%)$. Nilai kehilangan berat masing-masing jenis papan disajikan pada Gambar 4.
Mengacu pada data yang disajikan di atas, terlihat bahwa papan berlapis karton daur ulang dengan tingkat mortalitas rayap paling tinggi mengalami kehilangan berat paling rendah karena sedikitnya rayap yang melakukan aktifitas makan. Akan tetapi fenomena ini berbeda pada papan tanpa lapisan. Meskipun tingkat mortalitas sebesar $56 \%$ lebih tinggi dari papan berlapis finir, kantong semen, dan kayu solid, tetapi persentase kehilangan beratnya paling tinggi. Hal ini berarti kehilangan berat tidak semata ditentukan oleh jumlah individu rayap, tetapi juga oleh keaktifannya dalam mengurai bahan.

Pengamatan secara visual menunjukkan perilaku makan rayap yang berbeda untuk setiap jenis papan. Pada papan berlapis karton dupleks, dari 5 contoh uji, hanya 1 contoh uji yang mengalami serangan pada bagian kartonnya, sementara pada papan berlapis kantong semen seluruh contoh uji mengalami serangan pada bagian pelapisnya, bahkan serangan tersebut telah terjadi sejak pengamatan minggu pertama. Hal ini terjadi karena kantong semen merupakan kertas yang terbuat dari pulp kimia dimana persentase kandungan sellulosanya cukup tinggi (Meinander, 2000). Hasil pengamatan juga menunjukkan 


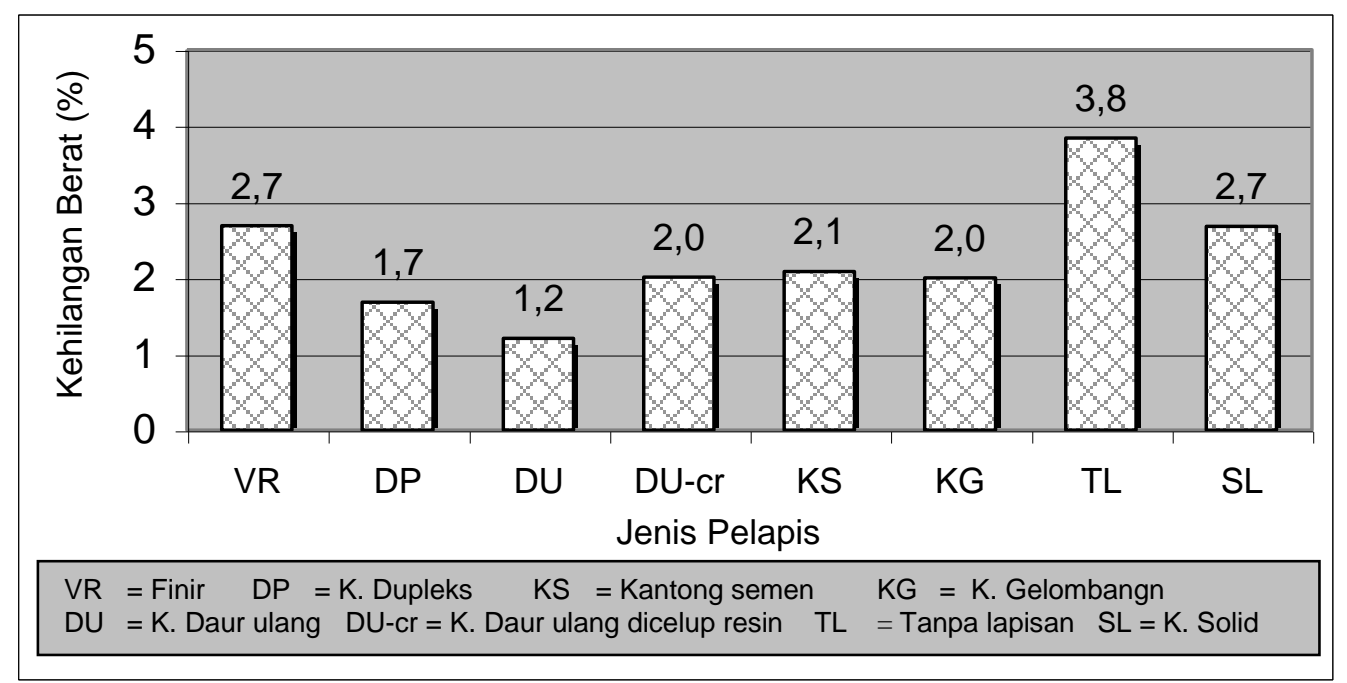

Figure 4. Weight loss percentages of samples caused by drywood termites attack

bahwa pada minggu III, rayap telah mampu melubangi contoh uji dan menyerangnya dari arah dalam, sedangkan pada minggu IV sebagian besar rayap telah masuk ke dalam lubang dan menyerang dari dalam. Perilaku ini merupakan implikasi dari karakteristik rayap yang bersifat kriptobiotik yaitu sifat rayap yang cenderung menyembunyikan diri dan menghindari cahaya (Prasetiyo dan Yusuf, 2005).

\section{Ketahanan Terhadap Rayap Tanah}

Untuk mengetahui ketahanan papan terhadap serangan rayap tanah, maka contoh uji telah diumpankan selama sebulan pada tempat yang terdapat koloni rayap Macrotermes sp., Microtermes sp., dan Coptotermes sp. Hasil pengamatan menunjukkan bahwa meskipun pada lokasi pengumpanan terdapat 3 jenis rayap, namun jenis rayap yang menyerang contoh uji hanya 2 jenis yaitu Macrotermes gilvus dan Microtermes spp. Secara umum, papan komposit kebanyakan diserang oleh jenis rayap macrotermes. Dari 5 contoh uji untuk masing-masing jenis papan, macrotermes menyerang $3-4$ contoh uji, sementara microtermes menyerang $1-2$ contoh uji. Fenomena ini berbeda pada contoh uji kayu solid. Dari 5 contoh uji yang diumpankan, seluruhnya terserang oleh jenis rayap microtermes. Rincian jumlah contoh uji yang terserang oleh masing-masing jenis rayap disajikan pada Tabel 3 .

Perbedaan jenis rayap yang menyerang masing-masing contoh uji menunjukkan adanya preferensi makan rayap pada berbagai jenis papan. Dilihat dari kemampuan jelajahnya, macrotermes sebagai jenis rayap tingkat tinggi memiliki kemampuan jelajah yang lebih tinggi dibandingkan microtermes, namun rayap tersebut agaknya memiliki preferensi yang lebih tinggi untuk menyerang papan komposit dibanding kayu solid. Kenyataan ini menunjukkan bahwa sifat isosianat

Table 3. Subterranean termite species attacking samples

\begin{tabular}{|c|c|c|c|}
\hline \multirow{2}{*}{ No. } & \multirow{2}{*}{ Jenis Papan } & \multicolumn{2}{|c|}{ Jumlah sampel yang terserang rayap } \\
\hline & & Macrotermes gilvus & Microtermes spp. \\
\hline 1. & Papan berlapis finir & 3 & 2 \\
\hline 2. & Papan berlapis karton dupleks & 3 & 2 \\
\hline 3. & Papan berlapis karton daur ulang & 3 & 2 \\
\hline 4. & Papan berlapis karton daur ulang dicelup resin & 4 & 1 \\
\hline 5. & Papan berlapis kantong semen & 4 & 1 \\
\hline 6. & Papan berlapis karton gelombang & 3 & 2 \\
\hline 7. & Papan tanpa lapisan & 3 & 2 \\
\hline 8. & Kayu solid & 0 & 5 \\
\hline
\end{tabular}




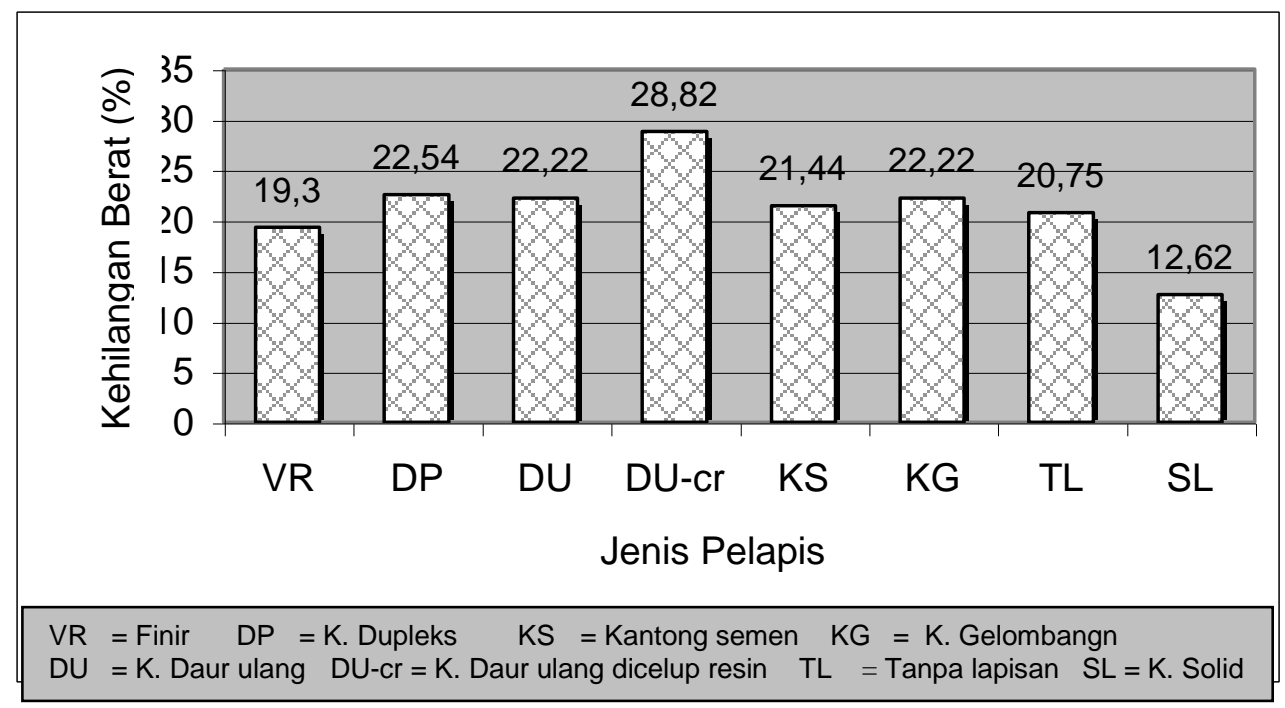

Figure 5. Weight loss percentages of samples caused by subterranean termite attack

yang dapat meningkatkan ketahanan papan terhadap biodeteriorasi kayu sebagaimana dikemukakan oleh Weaver dan Owen (1992) tidak berpengaruh secara nyata. Hal ini terjadi karena pada perekat water based polymer isocyanate yang digunakan, komponen isosianatnya sendiri hanya sekitar $15 \%$ dari berat total perekat cair.

Pengamatan pada minggu I menunjukkan adanya aktifitas rayap macrotermes pada 2 diantara 5 umpan kayu solid, tetapi pada minggu berikutnya aktifitas rayap tersebut sudah tidak ditemukan lagi. Diduga rayap ini meninggalkan kayu solid dan lebih memilih menyerang papan komposit. Kayu solid yang ditinggalkan oleh macrotermes ini kemudian diserang oleh microtermes.

Tingkat kehilangan berat contoh uji papan komposit berkisar antara 19,3-28,8\%, sementara kehilangan berat kayu solid hanya sebesar $12,6 \%$. Persentase kehilangan berat masing-masing contoh uji disajikan pada Gambar 3.

Gambar tersebut menunjukkan adanya variasi tingkat kehilangan berat masing-masing jenis contoh uji. Persentase kehilangan berat tertinggi terjadi pada jenis papan berlapis karton daur ulang yang dicelup resin, sementara jenis papan lainnya memiliki persentase kehilangan berat yang tidak berbeda jauh pada kisaran 19,3 $22,5 \%$.

Pengamatan secara visual menunjukkan fenomena yang berbeda antara kayu solid dengan papan komposit. Daerah serangan yang parah pada papan komposit kebanyakan pada bagian core contoh uji. Rayap lebih senang menyerang bagian tengah contoh uji, sementara bagian luarnya hanya terserang ringan. Fenomena ini berbeda dengan kayu solid, dimana serangan justru dimulai dari bagian terluar kayu ke tengah.

Papan komposit yang telah mengalami proses pengempaan pada suhu tinggi memiliki tingkat kerapatan yang berbeda dari luar ke tengah. Bagian tengah memiliki kerapatan paling rendah, sementara bagian luar memiliki kerapatan paling tinggi. Kerapatan dan kekerasan yang tinggi pada bagian luar papan nampaknya menjadi penghalang fisik (physical barrier) bagi rayap untuk menyerang papan. Umumnya contoh uji papan hanya mengalami serangan pada bagian pelapis karton atau kertasnya yang dilanjutkan dengan serangan langsung pada bagian tengah.

Hasil pengamatan juga menunjukkan bahwa pada papan komposit berlapis finir, tingkat serangan pada bagian finir sangat sedikit. Hal tersebut diduga dipengaruhi oleh jenis kayu dari finir yang digunakan. Jenis kayu dari finir yang digunakan adalah kayu waru (Hibiscus teleaceus). Jenis ini nampaknya kurang disukai oleh rayap sehingga rayap lebih senang langsung menyerang bagian tengah papan.

\section{KESIMPULAN}

Ketahanan papan komposit terhadap serangan rayap kayu kering relatif tidak berbeda dengan ketahanan kayu solid dari jenis kayu yang sama. Akan tetapi perilaku makan rayap pada setiap jenis papan komposit berbeda, dimana papan berlapis kantong semen lebih cepat 
mengalami serangan pada bagian permukaannya Rayap tanah Macrotermes gilvus memiliki preferensi yang lebih tinggi untuk menyerang papan komposit dibandingkan kayu solid, sementara Microtermes spp. lebih cenderung menyerang kayu solid. Pada pengujian terhadap rayap tanah, persentase kehilangan berat pada papan komposit lebih tinggi dari kayu solid yang disebabkan oleh perbedaan jenis rayap yang menyerang.

\section{DAFTAR PUSTAKA}

Nandika, D., Y. Rismayadi, dan F. Diba. 2003. Rayap: Perilaku dan Pengendaliannya. Muhammadiyah University Press. Surakarta.

Prasetiyo, K.W. dan S. Yusuf. 2005. Mencegah dan Membasmi Rayap Secara Ramah Lingkungan dan Kimiawi. Agro Media Pustaka. Depok.
Suhasman, M. Y. Massijaya, and Y.S. Hadi. 2005. The effect of Face and Back Layer Types on Composite Board Quality. Proceedings of the $6^{\text {th }}$ International Wood Science Symposium LIPI-JSPS Core University Program in the Field of Wood Science. Bali August 29-31, 2005. Pp. 241-247.

Meinander, P.O. 2000. Specialty papers. In: Paulapuro $H$. editor. Paper and Board Grades. Book 18 Papermaking Science and Technology. Cooperation with the Finnish Paper Engineers Association and TAPPI. Finlandia.

Weaver, F.W. and N.L. Owen. 1992. The Isocyanate-Wood Adhesive Bond. In: Plackett D V, Dunningham E A, compiler. Proceedings of the Pacific Rim Bio-based Composites Symposium; Rotorua New Zealand, 9 - 13 November 1992.

Diterima : 11 Desember 2007

\section{Suhasman dan Astuti Arif}

Lab. Keteknikan dan Diversifikasi Hasil Hutan

Fakultas Kehutanan Universitas Hasanuddin

Jl. Perintis Kemerdekaan Km. 10 Tamalanrea, Makassar 90245

Tlp./Fax. : (0411) 589592

E-mail: suhasman@yahoo.com

Muh. Yusram Massijaya dan Yusuf Sudo Hadi

Departemen Hasil Hutan

Fakultas Kehutanan, Institut Pertanian Bogor

PO. Box. 168 Bogor 16001

Telp. 0251-621285. Indonesia 